\title{
Hannah Arendt and Human Dignity: Theoretical Foundations and Constitutional Protection of Human Rights
}

\author{
John Helis \\ Department of Law, Carleton University \\ 1125 Colonel By Drive, Ottawa, Ontario, K1S 5BS, Canada \\ E-mail: jhelis@connect.carleton.ca
}

\begin{abstract}
This article considers how Hannah Arendt's understanding of human dignity comes to terms with two of the most significant controversies in contemporary human rights discourse, while also providing a sound basis for the application of the term. By focusing on the right to membership in a political community, Arendt's understanding of human dignity realizes the importance of maintaining the tension in the dichotomy present in two controversies: universalism and cultural specificity; natural law and positive law. The practicality of Arendt's approach will be demonstrated thought a review of a number of domestic and international human rights instruments with specific focus on the Canadian Charter of Rights and Freedoms, which thus far have failed to provide a universally accepted definition of the term.
\end{abstract}

Keywords: Human dignity, Hannah Arendt, Canadian Charter of Rights and Freedoms, Natural law, Positive law, Universalism, Cultural specificity, Controversies in human rights discourse

\section{Introduction}

The problems associated with the human rights project can be summed up in the simple phrase that it is trying to achieve too much for some in theory while at the same time achieving too little for others in practice. Critics of human rights point to the inadequacy of the concept of natural or inalienable rights both because of its historical failures and its theoretical insufficiencies. The most vocal critics consider human rights to be a new form of Western imperialism, and an affront to national sovereignty and culture (Note 1). In contrast, the proponents of human rights are facing the dual challenge of addressing concrete violations while at the same time responding to this theoretical assault (Note 2). This has led to an impasse on human rights.

This paper seeks to address some of the theoretical and practical problems associated with the foundations of human rights in light of the work of Hannah Arendt, whose corpus has only recently been tapped for its application to human rights (Isaac, 1996: p. 106). Arendt's work provides an appealing foundation for human rights because it moves away from the problematic idea of natural or inalienable rights and focuses on the right to membership in a political community with a basis in the concept of human dignity. This will be shown to provide a foundation for human rights while also coming to terms with the dichotomy in the following two controversies in contemporary rights discourse: universalism and cultural specificity; natural law and positive law. While human dignity is commonly referred to in human rights instruments, there is no universally accepted definition of the term, and even the Supreme Court of Canada has been inconsistent with its use of the concept. Arendt's understanding of human dignity will be shown to have practical application through a review of a number of human rights instruments throughout the world, with specific focus on the Canadian Charter of Rights and Freedoms.

\section{Hannah Arendt's Understanding of Human Dignity as a Foundation for Human Rights}

Hannah Arendt's work on human rights stems from her experiences during the Second World War and its aftermath: namely the Holocaust, the refugee crisis and mass statelessness. She asks why the concept of natural or inalienable rights failed humanity at the very time when they were needed most, despite having been pronounced for over a century and a half (1951: p. 287). She answers this question to the detriment of individualism by suggesting that individuals, without belonging to a political community, are not as sacred in themselves as the concept of individual human rights would suggest. The political empowered simply cannot relate to the disempowered as equal members of humanity. In the words of Arendt, "the world found nothing sacred in the abstract nakedness of being human" (1951: p. 295). As such, it has said that Arendt did not develop a comprehensive theory of human rights, but rather was more concerned with the problems associated with "the failures of the rights of man to secure human dignity" (Isaac, 1996: p. 64).

\subsection{Freedom in practice and in theory}

Arendt's concern with the practical realities of the effects of human rights violations should not divert attention from her 
theoretical approach. Indeed, she believed that the modern practical realities were in many respects an inevitable consequence of the Western tradition of political philosophy, one facet of which was a dichotomy between the practice and theory of freedom. As Peg Birmingham has noted, "it is clear that Arendt places the responsibility for the death camps squarely at the feet of a philosophically invalid and politically impotent notion of human rights" (2006: p. 5). Arendt traces the problem back to classical antiquity, where "freedom was an exclusively political concept, indeed the quintessence of the city-state and of citizenship" (1961: p. 157). In contrast to the practical political concept of freedom which developed in antiquity, political thought was developed by Greek philosophers in a way which was "explicitly in opposition to this polis and its citizenship. The way of life chosen by the philosopher was understood in opposition to

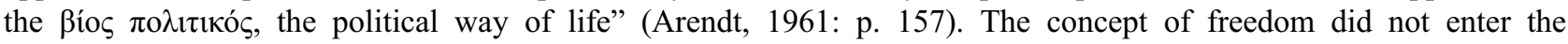
vocabulary of philosophy until relatively late in antiquity, and when it did it was used by thinkers such as Epictetus and St. Augustine to formulate a condition in which an individual could still remain free within one's own self, despite being deprived of it in the physical world (Arendt, 1961: pp. 146-147). This tradition carried forward into the thought of the modern philosophers, and Hobbes, Spinoza, and even Kant understood freedom outside of politics, and in fact believed that freedom increased when there was a decrease in politics (Hansen, 1993: p. 55). While perhaps providing some form of escape for the powerless individual, the theoretical slippery slope which this approach leads humanity down is the justification for "the notion that men can lawfully and politically live together only when some are entitled to command and the others forced to obey" (Arendt, 1958: p. 222). For Arendt the modern experience of totalitarianism, mass stateless and genocide are the end results of the slippery slope of political disempowerment, for which the concept of natural or inalienable rights failed to compensate.

Philosophy could no longer ignore the importance of political empowerment for the full realization of human potential. Political empowerment requires a genuine form of citizenship, and some of Arendt's most powerful writings account for the "disintegration of genuine citizenship, and the emergence of varieties of 'anti'-citizenship, false forms of what Arendt calls 'organized living together"' (Hansen, 1993: p. 7). The problem with the concept of natural or inalienable rights is that history has demonstrated that the rights of the disempowered will not be upheld by the politically empowered, and that displays the centrality of the right to belong in a political community which alone can guarantee what Arendt calls the "the right to have rights" (1951: pp. 294-295). The two uses of the word 'right' form distinct terms - the first of which is "a moral claim to membership and a certain form of treatment compatible with the claim to membership," while the second refers to the rights which belong to members of "an organized political and legal community" (Benhabib, 2004: pp. 56-57). Arendt is most concerned with the first of these two terms, and it is within this context that she introduces the concept of human dignity, which serves to distinguish between a citizen losing specific rights, and the loss of a "community willing and able to guarantee any rights whatsoever" (Benhabib, 2004: pp. 56-57). Arendt says that that one "can lose all so-called Rights of Man without losing his essential quality as man, his human dignity" (Benhabib, 2004: pp. 56-57).

The term human dignity is used by Arendt "in the Kantian sense and [she] believes that an activity or a form of life has dignity when it is intrinsically valuable and worthy of being undertaken 'for its own sake" (Parenkh, 1981: p. 2). Human dignity is connected to politics first through the use of Aristotle, who is the only political philosopher who finds intrinsic value in politics by differentiating between humans and other animals on the basis that they define their life course through the social process of politics (Parenkh, 1981: pp. 2-3). Aristotle's conception of political community is linked to human rights through Edmund Burke, who favoured the rights that come from "within the nation" over the "abstractions" of natural or inalienable rights (Arendt, 1951: p. 295).

The unique combination of Kant, Aristotle and Burke resulted in a rejection of the idea of natural or inalienable rights based on birth alone, and although in one respect this results in human rights becoming relative or culturally specific, a universal aspect is maintained in the concept of human dignity. Human rights are culturally specific because they are to be debated and brought to life in a political community. For Arendt, history has evidently shown the "pragmatic soundness" of Burke's conception of rights arising within a political community, which "seems beyond doubt in light of our manifold experiences" (Arendt, 1951: p. 295). However, at the same time a universal element is maintained in the insistence that human dignity must be maintained and that this can only be done through the guarantee of participation in a political community. This is best expressed by Peg Birmingham:

Arendt is able to reject the fiction of human nature and still think the inalienable right of the actor who in order to act must be able to appear in a public place of freedom. Though stripped of state and home, the actor must not be stripped of this fundamental right to be able to appear, because the first act, the act of beginning itself - the event of natality contains both the beginning and the its principle within itself (2006: p. 57).

The natality of Arendt referred to above is not simply the biological birth of a human. A merely biological understanding of natality is, of course, the basis for the natural or inalienable conception of rights which was outright rejected by Arendt. In order to understand Arendt's notion of natality one has to refer to her categorization of the three basic human actives: labour, work, and action. Action is considered the most important of the three for Arendt because 
while labour "is forced upon us by necessity," and while work is "prompted by utility," only action is entirely 'free' and 'gratuitous"' (Parenkh, 1981: p. 2). Arendt relies on Aristotle in asserting that labour and work cannot be termed "a way of life" because they are not "autonomous and authentically human" activities" (Tlaba, 1987: p. 1). Natality is connected to action because it is action alone which allows a person to use his or birth for a higher purpose and provides the "the capacity of beginning something anew" (Kharkhordin, 2001: p. 467). Being alive as a human being rather than merely a body requires one to act, speak and engage with others (Benhabib, 1996: p. 110). Humans thus require a public space in which they can develop their full potential through politics, "the activity of conducting the affairs of a community by means of speech" (Parenkh, 1981: pp. 131 \& 139). As Arendt describes it: In acting and speaking, men show who they are, reveal actively their unique personal identities and thus make their appearance in the human world, while their physical identities appear without any activity of their own in the unique shape of the body and sound of the voice (1958: p. 179).

\subsection{Human dignity and controversies in human rights discourse}

It is here that Arendt's understanding of human dignity comes to terms with two of the contemporary controversies surrounding human rights discourse. This conception of human dignity has important relevance to the debate on whether human rights are universally valid or rather based on the particular historical developments in the West. Cultural specificity in its purest form of course means that there is no objective human rights project which can be pursued. Although being less obvious than cultural specificity, universalism also results in a theoretical problem for human rights. In his review of what he terms 'Arendt's cosmopolitanism', Natan Sznaider demonstrates that the inherent weaknesses of universalism is that it "obliges us to respect others as equals as a matter of principle, but yet for that very reason it does not involve any requirement that would arouse curiosity or respect for what makes others different" (2007: pp. 112-113). Arendt is said to have pronounced a form of cosmopolitanism "beyond universalism," which is accomplished by maintaining "a tension between the universal and the particular" (Sznaider, 2007: p. 119). This tension means that human rights are debated and decided upon in particular political communities and are not in themselves inherent in nature. However, this requires a universal safeguard of human dignity; humankind's right to belong to a genuine political community in order to resolve issues of rights. This right to belong to a political community is thus the only universally valid right according to Arendt, from which the remaining rights arise through discussion and debate in particular political communities. In the same vein, this tension also allows us to come to terms with the controversy surrounding the dichotomy between natural law and positive law. Substantive rights arise from the positive laws of political communities. However, these rights can only come about through "the right to have rights," the first requirement of which is genuine belonging to a political community.

\section{Human Dignity in Human Rights Instruments}

The term human dignity has served a practical function in contemporary human rights regimes worldwide, and has been incorporated into the constitutions of a number of states as the basis for human rights protection. The first time that human dignity was incorporated into a legal text was in Germany after the Second World War. The German constitution, which is referred to as the Basic Law for the Federal Republic of Germany, states in Article 1 that "Human dignity shall be inviolable." This reference to human dignity in the German Basic Law has been interpreted by a majority of legal scholars as representing the objective basis for all the rights protected in the German constitution rather than serving as an independent civil right in itself (Erdman, Essert, \& Yachnin, 2003: para. 13).

Human dignity is also explicitly referenced in the constitutions of a number of other states. Section 1A of the Israel's Basic Law reads "The purpose of this Basic Law is to protect human dignity and liberty." In the constitution of South Africa, the term dignity is found in both the preamble of section 7 and as the subject of a specific right in section 10 . Section 10 reads: "Everyone has inherent dignity and the right to have their dignity respected and protected." It is not surprising that human dignity, especially in the Arendtian tradition, would be so profoundly appreciated in Germany, Israel and South Africa, as all three of these states have been founded on the aftermaths of the greatest deprivations of human dignity in modern history: the Holocaust and Apartheid.

\subsection{Human dignity in the international context}

It is also not surprising that human dignity is also explicitly referred to in a number of international human rights instruments, since the international human rights project was largely restored after the Second World War following the gross violations of human dignity. The first sentence of the preamble of the Universal Declaration of Human Rights reads as follows:

Whereas recognition of the inherent dignity and of the equal and inalienable rights of all members of the human family is the foundation of freedom, justice and peace in the world,

The preamble of the Universal Declaration makes a link between human dignity and the right to belong to a genuine political community by reference to the right to oppose tyranny: Whereas it is essential, if man is not to be compelled to have recourse, as a last resort, to rebellion against tyranny and oppression, that human rights should be protected by 
the rule of law,

A number of other international human rights instruments also refer to human dignity, such as the International Covenant on Civil and Political Rights and the International Covenant on Economic, Social and Cultural Rights.

\subsection{Human dignity in the Canadian context}

Although human dignity is not explicitly found in any of Canada's constitutional texts, the Supreme Court of Canada refers to the term on a regular basis when interpreting the rights enumerated in the Charter, and it is found in the preamble of the quasi-constitutional Canadian Bill of Rights, which states in the first paragraph:

The Parliament of Canada, affirming that the Canadian Nation is founded upon principles that acknowledge the supremacy of God, the dignity and worth of the human person and the position of the family in a society of free men and free institutions.

While the preamble of the Charter does not refer to human dignity, it does refer to the supremacy of God - as does the preamble of the Canadian Bill of Rights. The preamble of the Charter reads as follows:

"Whereas Canada is founded upon principles that recognize the supremacy of God and the rule of law."

Interestingly, it has been argued that this reference to the Supremacy of God in the Charter represents human dignity, which is the theory "upon which the Charter is based" (Penny \& Danay, 2006: para. 4). It has also been suggested that if human dignity was linked to the supremacy of God there would be "a more coherent and robust elaboration of the Charter's moral architecture" (Sossin, 2003: p. 228).

More importantly, the Supreme Court of Canada has referred to human dignity as the basis for the substantive rights and as lying "at the heart of the Charter" (R. v. O'Connor, 1995: para. 63). In R. v. Morgentaler Justice Wilson held that "the idea of human dignity is expressed in every Charter provision and stands as the basic theory underlying the Charter" (1986: p. 166). Thus, human dignity is not a single substantive right itself, but rather a theoretical basis upon which the substantive rights are anchored.

The Supreme Court's analysis of section 1 of the Charter brings the analysis close to Arendt's view of linking human dignity with participation in a political community. Section 1 gives life to the substantive rights enumerated in the provisions that follow, and also provides the justifiable limitations to those rights. Section 1 reads as follows:

The Canadian Charter of Rights and Freedoms guarantees the rights and freedoms set out in it subject only to such reasonable limits prescribed by law as can be demonstrably justified in a free and democratic society.

In R. v. Oaks, the leading decision from the Supreme Court on section 1, Chief Justice Dickson made a crucial link between the idea of human dignity and participation in political community by stating that:

The Court must be guided by the values and principles essential to a free and democratic society which I believe embody, to name but a few, respect for the inherent dignity of the human person, commitment to social justice and equality, accommodation of a wide variety of beliefs, respect for cultural and group identity, and faith in social and political institutions which enhance the participation of individuals and groups in society (1986: p. 136).

This view was subsequently approved unanimously by the Supreme Court in the Quebec Succession Reference case when analysing the unwritten constitutional principle of democracy (1998: para. 64).

This is not to suggest that the international human rights instruments, the constitutions of various states, and the Supreme Court of Canada have fully adopted Arendt's understanding of human dignity. The examples presented display how aspects of Arendt's approach have been successfully used. It needs to be stressed that the term human dignity has also been applied in a number of ways which are inconsistent with Arendt's view. The Supreme Court of Canada has in fact been criticised for "failing to develop a coherent approach to" its use of the term human dignity (Fyfe, 2007: para. $3)$.

In many cases, the term human dignity has been used as a justification for a specific right. For example, the Supreme Court of Canada has often relied on the term human dignity when analysing the right to life, liberty and the security of the person in section 7 of the Charter. The provision reads as follows:

Everyone has the right to life, liberty, and security of the person, and the right not be deprived thereof except in accordance with the principles of fundamental justice.

In addition to endorsing the idea that human dignity underlies the entire Charter, Justice Wilson in the Morgentaler case also relied on the term when interpreting section 7, and held that it provides "a degree of personal autonomy over important decisions intimately affecting their private lives" (1986: p. 171). This is completely contrary to Arendt's view of human dignity, and in fact is reflective of the aspect of liberalism which she highly critical of, which equates freedom with the individual's right to carry out essentially private activities. This liberal conception of freedom, which Arendt finds to be concisely characterized in the credo, "the less politics the more freedom," is contrary to her notion of linking freedom to action in the political realm (Arendt, 1961: p. 149). However, it may still be possible to reconcile this 
position with Arendt's understanding of human dignity. As Jürgen Habermas has indicated, once humans have achieved a degree of material equality in their private lives, they will then want to "live in a world ordered by Hannah Arendt's notion of equal participation, defending the liberty of all against the threat of domination by any group or individual" (May, 1986: p. 88).

While Arendt's understanding of human dignity is most compatible with the view that it underlies the Charter as a whole, it can also form part of the analysis of a specific right, provided that it is consistent with the purpose of enhancing the ability of an individual or a group to engage in political action. For example, in the case of F.C.W., Local 1518 v. K-Mart Canada Ltd., the court linked the notion of human dignity to the freedom of expression guaranteed in section 2(b) of the Charter (1999). While this case concerns the freedom of expression within the context of a labour dispute, which at face value is outside the ambit of Arendt's understanding of human dignity, the case on the whole does serve to underscore the importance of "free expression as a means to social and political empowerment" (Fyfe, 2007: para. 15). Indeed, it difficult to envision how Arendt's understanding of human dignity can be actualized without the freedom expression.

Arendt's view of human dignity is well suited for cases involving the freedom of expression, but it can also have practical application in cases involving the equality right as guaranteed by section 15 of the Charter. Arendt believed that equality was only possible when "unequal people have equal rights," which requires the "concrete difference themselves are organized into the political realm" (Hansen, 1993: p. 138). Section 15(1) of the Charter reads as follows:

15(1) Every individual is equal before and under the law and has the right to the equal protection and equal benefit of the law without discrimination and, in particular, without discrimination based on race, national or ethnic origin, colour, religion, sex, age or mental or physical disability.

This section of the Charter is particularly well suited to be interpreted in light of Arendt's understanding of human dignity as it organizes the concrete difference that have traditionally denied people full participation in the political and legal systems. In Law v. Canada, the foundational case for the interpretation of section 15, Justice Iacobucci had the following to say about human dignity:

Human dignity means that an individual or group feels self-respect and self-worth. It is concerned with physical and psychological integrity and empowerment. Human dignity is harmed by unfair treatment premised upon personal traits or circumstances which do not relate to individual needs, capacities, or merits. It is enhanced by laws which are sensitive to the needs, capacities, and merits of different individuals, taking into account the context underlying their differences. Human dignity is harmed when individuals and groups are marginalized, ignored, or devalued, and is enhanced when laws recognize the full place of all individuals and groups within Canadian society (1999: para. 53).

This definition appears to have some of the characteristics of Arendt's understanding of human dignity. However, the court also acknowledges that "there can be different conceptions of what human dignity means," and unfortunately does not establish which is the most appropriate (1999: para. 53).

\section{Conclusion}

Hannah Arendt's understanding of human dignity comes to terms with some of the most significant controversies in human rights theory, while at the same time providing a practical basis for the application of human rights law. Rather than attempting to solve the tension between universalism and cultural specificity, and between natural law and positive law, Arendt comes to terms with it and focuses on the need for constant dialogue to maintain the optimum balance. The lack of a universally accepted definition of human dignity has lead one commentator to describe the Supreme Court of Canada's approach as "muddled and inconsistent," and recommend that the term "be excised from Charter discourse altogether" (Fyfe, 2007: para. 54). Arendt's view of human dignity is a suitable alternative to this proposition. This approach reminds us that rights are not automatically protected simply because the political community in the distant past enshrined them in a written constitution. A constitution for Arendt requires continuous action by the body politic as a whole and constant commitment to live by it (McGowan, 1998: p. 88).

\section{References}

Arendt, H. (1951). The Origins of Totalitarianism. New York: Harcourt, Brace \& Co.

Arendt, H. (1958). The Human Condition. Chicago: The University of Chicago Press.

Arendt, H. (1961). What is Freedom? In H. Arendt, Between Past and Future: Six Exercises in Political Thought (143-172) New York: The Viking Press.

Benhabib, S. (1996). The Reluctant Modernism of Hannah Arendt. Thousand Oaks: Sage Publications.

Benhabib, S. (2004). The Right of Others: Aliens, Residents and Citizens. Cambridge: Cambridge University Press.

Birmingham, P. (2006). Hannah Arendt and Human Rights: The Predicament of Common Responsibility. Bloomington \& Indianapolis: Indiana University Press.

Derwent, M. (1986). Hannah Arendt. New York: Penguin Books Ltd. 
Erdman, J., Essert C. \& Yachnin M. (2003). An Interview with Justice Frank Iacobucci and Professor Dieter Grimm. University of Toronto Journal of Law and Equality, 2, 197-209.

Fyfe, J.R. (2007). Dignity as Theory: Competing Conceptions of Human Dignity at the Supreme Court of Canada. Saskatchewan Law Review, 70, 1-26.

Hansen, P. (1993). Hannah Arendt: Politics, History and Citizenship. Stanford: Stanford University Press.

Isaac, J.C. (1996). A New Guarantee on Earth: Hannah Arendt on Human Dignity and the Politics of Human Rights. American Political Science Review, 91(1), 61-73.

Kharkhordin, O. (2001). Nation, Nature and Natality: New Dimensions of Political Action. European Journal of Social Theory, 4(4), 459-478.

McGowan, J. (1998). Hannah Arendt: An Introduction. Minneapolis: University of Minnesota Press.

Parenkh, B. (1981). Hannah Arendt and the Search for a New Political Philosophy. Atlantic Highlands: Humanities Press.

Penny, J.W. \& Danay, R. (2006). The Embarrassing Preamble? Understanding the "Supremacy of God" and the Charter. University of British Columbia Law Review, 39, 287-331.

Sossin, L. (2003). The 'supremacy of God', Human Dignity and the Charter of Rights and Freedoms. University of New Brunswick Law Journal, 52, 227-242.

Sznaider, N. (2007). Hannah Arendt's Jewish Cosmopolitanism: Between the Universal and the Particular. European Journal of Social Theory, 10 (1), 112-122.

Tlaba, G.M. (1987). Politics and Freedom: Human Will and Action in the Thought of Hannah Arendt. Lanham, New York and London: University Press of America.

Legislation

Basic Law for the Federal Republic of Germany, (Promulgated by the Parliamentary Council on 23 May 1949) (as Amended by the Unification Treaty of 31 August 1990 and Federal Statute of 23 September 1990).

Basic Laws of Israel.

Canadian Bill of Rights, S.C. 1960, c. 44.

Canadian Charter of Rights and Freedoms, Part I of the Constitution Act, 1982, being Schedule B to the Canada Act 1982 (U.K.), 1982, c. 11.

Constitution of the Republic of South Africa ( No. 108 of 1996).

International Covenant on Civil and Political Rights, Adopted and opened for signature, ratification and accession by General Assembly resolution 2200A (XXI) of 16 December 1966 entry into force 23 March 1976, in accordance with Article 49.

International Covenant on Economic, Social and Cultural Rights, Adopted and opened for signature, ratification and accession by General Assembly resolution 2200A (XXI) of 16 December 1966 entry into force 3 January 1976, in accordance with article 27.

Universal Declaration of Human Rights, Adopted and proclaimed by General Assembly resolution 217 A (III) of 10 December 1948.

Jurisprudence

F.C.W., Local 1518 v. K-Mart Canada Ltd., (1999) 2 S.C.R. 1083, 176 D.L.R. (4th) 607.

Law v. Canada (Minister of Employment and Immigration), (1999) 1 SCR 497; 170 DLR (4th) 1.

Reference Re Secession of Quebec, (1998) 2 S.C.R. 217, 161 D.L.R. (4th) 385.

R. v. Morgentaler, (1986) 2 S.C.R. 284, 31 D.L.R. (4th) 569.

R. v. Oaks, (1986) 1 S.C.R. 103, 26 D.L.R. (4th) 200.

R. v. O'Connor, (1995) 4 S.C.R. 411, 130 D.L.R. (4th) 235.

\section{Notes}

Note 1. See for example - Ding, Y. (1989). Opposing Interference in Other Countries' Internal Affairs Through Human Rights. Beijing Review, 32, 14-16.

Note 2. See for example - Tharoor, S. (1999/2000). Are Human Rights Universal? World Policy Journal, 16(4), 1-6. 